\title{
Study on the Construction of Enterprise Quality Culture for Brand Strategy
}

\author{
Zhi Gao, Jinfu Ye, Yi Huang \\ School of Management, Northwestern Polytechnical University, Xi’an, China. \\ Email: dazhi1217@163.com,yjf@nwpu.edu.cn,280963827@qq.com
}

Received May 22 ${ }^{\text {nd }}, 2012$; revised June 22 ${ }^{\text {nd }}, 2012$; accepted July 22 ${ }^{\text {nd }}, 2012$

\begin{abstract}
Enterprise quality culture is an important part of corporate culture, but it is often overlooked by enterprise, thus restricting quality level and quality image improvement to a large extent. In this paper, the construction of enterprise quality culture is deeply discussed, aiming at helping enterprise deeply understand the essence of quality culture, combining with brand strategy for the construction of enterprise quality culture.
\end{abstract}

Keywords: Quality Culture; Brand Strategy; Quality Culture Construction

\section{Introduction}

Brand competition has become the domestic and international market competition mainstream. To survive and develop, enterprise must implement the brand strategy. As the core of corporate culture, quality culture plays an irreplaceable role for implementing brand strategy; brand is an important indicator of corporate quality culture. Therefore, this article will be combine product quality with brand strategy to discuss the building of quality culture. It has an important significance for the brand strategy implementation and quality culture construction.

\section{An Overview of Quality Culture}

\subsection{The Meaning of Quality Culture}

The meaning of the quality culture is still not a unified understanding. Experts in various fields from different perspective give different interpretations to quality culture. Liu Lemin believes that the quality culture be the quality as the center, based on the material culture, consist of quality consciousness, quality standard, quality management art, quality improvement innovation and other spiritual and cultural activities [1]. Zhou Ye argues that quality culture refer to the enterprise and society in the long-term production and management naturally forming a series of quality problems concerning quality consciousness, norms, values, ethics, philosophy, innovation consciousness, behavior rules, ways of thinking, competitive consciousness, legal concept, customs, traditional idea, enterprise environment, enterprise system and so on. Quality value is the core of quality culture [2].
Jia Hong believes that quality culture form in the enterprise in the establishment and development process and rooted in the minds of all members of the enterprise, deciding all the production activities of a series of qualityrelated values and norms [3].

Although the definition of quality culture is not uniform, each presentation is different. But on quality culture still has many similarities and common. This paper takes the scholars of our country, Ning Hong's point of view: quality culture is the enterprise in long-term quality management process, enclose quality problems arising from the activities of all manners, this approach reflects the enterprise unique quality viewpoint of value. Including the enterprise standard, value orientation, moral concepts, innovative consciousness, way of behavior, competitive consciousness, legal concept, customs, traditional concepts, the goal of enterprise, enterprise system, enterprise image and so on. It not only shows the enterprise culture's function and nature, but also for marketing refers to the total product concept of entirety [4].

\subsection{The Characteristics of Quality Culture}

Quality culture is the core part of corporate culture, which influenced by social culture, so the quality culture is also influenced by the social environment and social morality. A good group quality awareness and quality psychology has great help on enterprise quality culture establishment. Quality culture is a unique culture, with its characteristics of culture. As a kind of culture it is distinguished from other corporate phenomenon or activity. The characteristics of quality culture include the fol- 
lowing respects:

- Uniqueness: each enterprise has its own history, types, nature, scale, psychological background, the quality of personnel etc;

- Mutability: the formation of quality culture, not only influenced by the enterprise traditional spirit factors, but also influenced by the reality of management environment and management process;

- Objectivity: it is rooted in the enterprise long-term production and management practice, not created or rely on empty preaching can build up;

- Sociality: it is the special form of social culture in enterprise, also known as the "sub-culture", the different social system has different quality culture;

- Inheritance: it emphasis on traditional values, code of conduct and spiritual culture's role in management, and this point in the previous management theory is not recognized;

- Epochal character: it belongs to the sub culture level, exist in a state of social material and cultural living environment, must reflect the times style and requirements, and maintain synchronization with the development of the times.

\subsection{The Structure of Quality Culture}

From the time of the cross section, the structural characteristics of quality culture consists of its material level, system level and mental level, the three level according to the order from low to high together component of quality culture pyramid, and accordance with culture change features, quality culture change characteristics from the material level to the spiritual level increases gradually. Among them, the material level has a high visibility, belongs to low level of quality culture, but the system level and mental level has a low easy to perceive, belongs to deep level of quality culture.

\subsubsection{The Material Level of Quality Culture}

The material level is the basic level of quality culture, such as: clothing factory, factory emblem, factory song, products and the quality image. On the effect sizes, compared with other aspects, material level has relatively small influence on cultural strength.

\subsubsection{The System Level of Quality Culture}

Quality culture system is the main mechanism of shaping the corporate member behavior. The system level includes the following three aspects, namely, standardization and standard system, incentive system and legal system. Among them, standardization and standard system provide the guidance and evaluation system for behavior and its results, reveal basic goal of quality practice, to meet the need or expectation. Reward system reflects incentive and oriented action to the pattern of behavior.

\subsubsection{The Spirit Level of Quality Culture}

The spirit level of quality culture is located in the top of quality culture pyramid, which is the core content and the highest realm of quality culture, and also can reflect the quality culture construction achievements. It shows the community actively to respect and protect the interests of customer's value orientation and spiritual pursuit. Spirit level involves the following four groups value orientation, respect customer equity; actively maintain social quality culture authority; pursuit of behavior results from the social benefit and perfectionism; and in a continuous and persistent view to treat economic resources, promote social sustainable development concept.

\subsection{The Importance of Quality Culture to the Enterprise}

Quality culture has four functions to enterprise, they are guiding role, constraint effect, agglomeration effect and radiation effect.

- Guiding role: the goals of employees are directed to the corporate objectives. Employees will accept common values and form a force to the given direction in the influence character by environment;

- Constraint effect: as an organization, the enterprise often need to make many rules and regulations to ensure the quality of products and work, which of course is absolutely necessary, but even with ten million rules and regulations, it is difficult to regulate the behavior of every worker. Quality culture is an invisible constraint forces to form a code of conduct to restrict the behavior of the workers, which can compensate for the lack of rules and regulations;

- Agglomeration effect: quality culture is a kind of strong cohesion force, uniting various levels of people around the enterprise culture so as to produce a cohesive and centripetal force, and share the joys and sorrows with enterprise;

- Radiation effect: quality culture shapes the enterprise's quality image. Good enterprise image is a sign of success, the enterprise quality image not only has big effect to enterprise itself, but also to the region and the domestic and foreign enterprises. So the quality culture has great radiation effect.

Such as Shanghai Bell Company, in order to shape the quality culture, setting up a special management system of quality culture, and achieving great success [5]. Wuhan iron and steel corporation builds quality culture for many years, forming continuous improvement mechanism for product quality, equipment features and user services, improving service quality levels, through unremitting efforts, the Wuhan iron and steel corporation in- 
creases products quality, market reputation and customer satisfaction [6].

\section{Brand Strategy and Quality Culture Relations Research}

\subsection{Enterprise's Brand Strategy Begins in Quality Management}

The brand is to provide customers with a worthwhile purchase value functional benefits and added value products, the enterprises to establish brand is intended to enable consumers to identify their products and services, therefore, brand evaluation authority is the customer [7]. Customer satisfaction evaluation provides scientific basis for corporate brand strategy, guide an enterprise to walk along quality benefit road. A good brand can bring customer interests, to create value. Therefore, to implement brand strategy, at first to strengthen quality management, improve customer satisfaction.

\subsubsection{Customer Satisfaction Is an Important Means for Enterprise Quality Management}

Customer satisfaction index (CSL) evaluation has important significance to improve the product quality and business performance.

\subsubsection{Create Significant Economic Benefits}

Products are designed to be better, the more can improve its target customer satisfaction level; on the contrary, if the product or service is poor, customer satisfaction is low. Customer satisfaction influences the sales revenue of the enterprise and the economic benefits of the enterprise. The United States "fortune" magazine selected "global top 500 enterprises" inclusion in the CSL evaluation of enterprises, tracking compared the year sales volume and the market value with the respective CSL and found that enterprises' CSL have significant direct relationship with the "economic growth" and "market proliferation".

\subsubsection{Improve the Management Level of Enterprises} Quality is the life of enterprise. Customer satisfaction index reflects the needs of the markets. The index can reflect the market recognized degree to enterprises. Enterprises through customer satisfaction can continue to identify service quality problems, so as to facilitate the enterprise take improvement measures rationally.

\subsubsection{Promote the Building of Enterprise Culture}

The enterprise culture includes enterprise member's values, business philosophy, thinking way and behavior way, has powerful cohesive action to the enterprise. Customer satisfaction philosophy advocates the unity of customer and business interests and in-depth understanding of customer needs. Developing the evaluation of client satisfaction is conducive to cultivating enterprise interior staff for business identity, forming a good team spirit, guiding all the enterprises internal quality activity toward the enterprise and customer development.

\subsubsection{The Core of Brand Is Quality}

Brand evaluation authority is the customers, no customers no brand. The customer to the brand cognition is based on the customer using products. Products and services quality finally decides the customer to the product brand or company loyalty and recognition level, namely the customer purchase quality. Therefore, to build the brand first grab from quality, Haier Group is an example in this regard. In the process of quality management in Haier, take the management method, namely the overall control and management, each day to do every thing, today's work must be finished today, today completed work must be improved than yesterday, tomorrow's goal must be higher than today. Haier products and services are unique, emphasis on pre-sale, sale, the after-sales service. It is management and service features that huge upgrade the Haier brand image, show its contest ability in the international market. Therefore, the implementation of brand strategy, the creation and development of famous brand products, the core is still quality. Only those who are committed to quality improvement and innovation, can to be successful, to be profitable, can move toward prosperity.

\subsubsection{The Soul of Brand Is Culture}

The brand derives from enterprise culture, benefit, market, trademark is merely technical, short-term, microscopic things, more effective, more profound, and in general more influential is the unique culture and values of the design, this is the brand essence. For example, in 1956 IBM company first lift cultural banner, with "science, innovation, excellence" orientation, successfully established the "blue giant image" in world high-tech domain. Since then, the IBM brand squeezes in the world's ten major brands list.

\subsection{Advanced Quality Culture Is the Key to the Sustainable Development of the Brand}

Quality culture as a component of corporate culture, is the enterprise internal explicit or implicit method and mechanism for dealing with quality problems [8]. Quality for a enterprise, reflects the management, technology and the overall level of corporate culture. In other word, quality is the eternal theme and the first life of enterprises, a corporate quality culture quality embodies the enterprise quality improvement capacity. To establish and improve the quality culture system, update the con- 
cept of quality, strengthen the sense of quality, breed spirit of enterprise quality, enhance the enterprise staff quality, all contribute to the improvement of the enterprise as the main body of quality improvement mechanism, enhance corporate brand awareness and the potential of sustainable development.

\subsubsection{Enterprise Quality Concept Determines the Behavior of Enterprise Quality Culture}

The key to construction of enterprise quality culture is a corporate quality policy and objectives as well as the formation of a set of perfect system of quality system documents, through quality management agencies and the joint efforts of all staff, rooted in the daily management and settled in practice [9]. In the quality improvement process, the enterprise value plays an important regulatory role. Therefore, attention should be paid to the staff to corporate values education, let enterprise quality values into all the staff of the enduring spirit and style, make the enterprise good quality system and standard into spiritual strength, the pursuit of first-class products and meet the greatest needs of users as its eternal goal.

\subsubsection{Enterprise Quality Culture Influences the Enterprise Brand}

Enterprise quality culture is the outcome of modern market economy, is intangible assets relevant to enterprise brand, is a kind of special product. As a form of culture, enterprise quality culture has cultural oriented function, incentive function, coagulation function, constraint function and radiation function, it can enable enterprises to enhance cohesion, competitiveness and vitality, and constantly improve the enterprise value creation. Enterprise quality culture influence the brand of the enterprise, is crucial to the enterprise sustainable development, many enterprises are able to success, owe to its corporate quality culture support and contribution. So, every successful enterprise must have its own quality culture, use quality culture to promote the quality and brand development.

\subsection{Quality Culture and Brand Strategy Mutual Support and Common Development}

To implement brand strategy, should from brand creation, brand positioning, brand image and other links to create brand. Brand building by input quality culture, implement brand operation. Brand exists scale benefit, only brand without scale, market share can't expands, so can't form famous brand; on the contrary, only scale no brand, then scale also won't last long. Therefore, the enterprise must improve and maintain brand in intrinsic quality as well as expand existing brand scale. Strengthening material basis for enterprise quality culture construction, thereby provide the necessary material guarantee for the implementation of brand strategy.

\subsubsection{Quality Culture Can Promote the Implementation of Brand Strategy}

Enterprise is the carrier for brand strategy implementation, good corporate culture can enhance the cohesion and centripetal force, coordinate the relation between departments, perfect various incentive mechanism, enhance employee brand initiative and enthusiasm, improve their brand awareness.

\subsubsection{Enterprise Value Is the Core Guarantee of Brand Strategy}

Quality consciousness is the important component of enterprise value. No high quality products as a basis, brand is not possible. Therefore, the enterprise must strengthen the quality management, process continuous quality improvement and innovation. Do the best to meet customer requirements of quality level.

\subsubsection{Set Up the Good Enterprise Image}

Quality culture is the concentrated embodiment of enterprise image. Under the condition of market economy, there is no good corporate image and business reputation, it means that enterprises have no broad market, more do not talk to go up the implementation of brand strategy. Therefore enterprises have to carefully design and plan, establish a good corporate image, convey corporate values and culture through the brand to customers, maximize customer recognition, so as to implement brand strategy successfully.

\section{Study on the Construction of Corporate Quality Culture for Brand Strategy}

\subsection{Leader Attention and Physically Execution}

In achieve excellent quality of all the elements, senior management effective leadership is the most important. Top management needs to develop quality strategy, make a good corporate quality culture construction and innovation plan designer, advocate promoters and tissue builders. Top management involvement in quality improvement activities will take them some time, it is a big investment to busy them, but must believe that such investment is required. Only the top really join into these activities, show to the staff that this activity is important, thus stimulating their enthusiasm to participate in quality improvement activities.

Through the leadership quality training, management layer can show staff their quality activity execution. Managers can through this way to give subordinates with some management training. A concept mentioned in this kind of activity by managers will be using in daily work by lower manager. 


\subsection{Efficient Management and Continuous Improvement}

Companies need middle managers, supervisors and employees to common executive quality strategy made by senior management. The quality department should study and be familiar with the quality work, combine with the actual situation of enterprises, sum up enterprise quality strategy, quality policy, quality concept, quality maxim, quality of technical specifications and other quality culture construction content, and propaganda; middle management should focus on solving some of their problems to be solved, such as product development process efficiency problem, in the selection of new quality level decision quality problem, high cost management problems. For the employees, we believe that all employees are expected to be management and expert.

\subsection{Full Participation and Indefatigably Striving}

The main body of enterprise is employees, the enterprise's expectation lies in cohesion and centripetal force of staff, and the sense of responsibility and mission. Quality value is the core elements of quality culture, is the enterprise staff to quality consensus, is the essential deciding enterprise success or failure, through training the staff quality values, to stimulate the staff's power source, so as to give full play to their wisdom, initiative, enthusiasm and creativity. Take the quality into staff's consciousness, quality culture can become the most active factor in construction of enterprise culture. Should pay attention to creating opportunities for the staff, to strengthen quality education, standardized management, technical training work, and make the quality education regularly, and institutionalization. For staff to create a good working environment and harmonious interpersonal atmosphere, in the aspects to care for them, help them, understand them, meet staff needs of self, only when the individual development and enterprise development consistently, staff is a true master, can play a positive intelligence.

\section{Conclusion}

Creating brand, requires extensive absorption of various cultures, combine with the improvement and innovation, building enterprise characteristics brand culture. Enterprises should carry out brand strategy as the important content of the construction of quality culture, and establish a good corporate image to provide guarantee for the implementation of brand strategy. Quality reflects an enterprise quality culture quality, enterprise quality concept determines the behavior of enterprise quality culture, quality culture affects the survival and development of enterprises. Therefore, the establishment of advanced quality culture, is conducive to the implementation of brand strategy. Quality culture is the concentrated embodiment of enterprise image. Therefore enterprises have to carefully design and plan, establish a good corporate image, so as to implement brand strategy successfully.

\section{REFERENCES}

[1] L. M. Liu, "On Enterprise Quality Culture Aesthetic Evaluation," Journal of Metallurgical Standardization and Quality, Vol. 18, No. 1, 2000, pp. 69-72.

[2] Y. Zhou, J. S. Zhou and J. F. Chai, "Study Quality Management under the Environment of Supply Chain,” Logistics Technology, Vol. 10, No. 2, 2006, pp. 25-29.

[3] H. Jia, "Enterprise Quality Culture Construction and Enterprise Quality Management,” Journal of Engineering Quality, Vol. 46, No. 10, 2003, pp. 175-180.

[4] H. Ning, "Discussion on Enterprise Quality Culture Significance," Journal of Science and Technology Information, Vol. 5, No. 18, 2008, pp. 71-76.

[5] W. Zi, "Quality Culture Construction of Enterprise-A Case Analysis,” Journal of Shanghai Quality, Vol. 11, No. 12, 2011, pp. 18-20.

[6] Z. Fen, "Quality Culture Construction of Wuhan Iron and Steel Corporation,” Journal of Metallurgy Enterprise Culture, Vol. 9, No. 1, 2012, pp. 52-53.

[7] X. F. Tang, "Quality Management after Walking into the WTO,” Standards Press of China, Beijing, 2002, pp. 211221.

[8] F. R. Han, “Modern Quality Management,” Mechanical Industry Press, Beijing, 2003, pp. 123-134.

[9] T. Conti and Y. Koudo, “Twenty-First Century Quality,” Renmin University Press of China, Beijing, 2005, pp. 26374. 